\title{
Phylogenetic relationships in the genus Apis inferred from mitochondrial DNA sequence data
}

\author{
L Garnery 1, D Vautrin 2 JM Cornuet ${ }^{*}$, M Solignac 2 \\ 1INRA-CNRS (URA 1190), Laboratoire de Neurobiologie, \\ Comparée des Invertébrés, 91440, Bures-sur-Yvette, France; \\ 2 CNRS, Laboratoire de Biologie et Génétique Evolutives, Avenue de la Terrasse, \\ 91198 Gif-sur-Yvette, France
}

(Received 11 January 1991; accepted 13 February 1991)

\begin{abstract}
Summary - The nucleotide sequence of the $5^{\prime}$ end of the mitochondrial cytochrome-oxydase subunit II gene was obtained through direct sequencing of PCR (Polymerase Chain Reaction) product from 4 Apis species (mellifera, cerana, dorsata and florea) and Bombus lucorum (Apidae) and Xylocopa violacea (Anthophoridae) as outgroups. Phylogenetic trees were built using Neighbor-Joining and parsimony methods. Three branches, dorsata, florea and cerana-mellifera diverged almost simultaneously and cerana separated from mellifera later but not as early as generally thought.
\end{abstract}

Apis/Phylogeny/molecular systematics/mitochondrial DNA/nucleotide sequence/cytochromeoxydase

\section{INTRODUCTION}

To-date, phylogenetic relationships between the species of the genus Apis are mainly based on morphological, ecoethological and biogeographic considerations (Ruttner, 1988). Recently, a phylogenetic tree has been obtained from allozyme data (Sheppard and Berlocher, 1989). In addition, preliminary reports of molecular systematics of Apis species have been presented by MacPheron (1989) and Sheppard (1989). In this rapid communication, we provide sequence data of the mitochondrial subunit II of the cytochrome-oxydase gene (CO-II) which allow to infer phylogenetic relationships between Apis cerana, A dorsata, A florea and $A$ mellifera.

\section{MATERIALS AND METHODS}

\section{Origin of samples}

Individuals of $A$ cerana, $A$ dorsata and $A$ florea were sampled in Faridpur (Bangladesh) during January 1990. A cerana and $A$ dorsata were taken from feral nests and workers of $A$ florea were caught when they were feeding on palm sugar. A mellifera (subspecies mellifera) is represented by a colony from France. A second

\footnotetext{
* Correspondence and reprints.
} 
sequence was taken from the literature (Crozier et al, 1989) for $A m$ ligustica. Two other species have been used as an outgroup: Bombus lucorum (Apidae, Bombinae) and Xylocopa violacea (Anthophoridae, Xylocopinae). One individual of each species was caught in Bures.

\section{Extraction of DNA}

mtDNA from Apis mellifera was cloned in pUC8. For the other species, total DNA was extracted from single individuals (one individual per species) according to Kocher et al (1989). The head and thorax for the small $A$ florea and the head alone for the other species were ground in $750 \mu$ of extraction buffer (Tris- $\mathrm{HCl} 100 \mathrm{mmol}^{-1}{ }^{-1}$, pH 8.0, EDTA $1 \mathrm{mmol}^{-1} \mathrm{I}^{-1} \mathrm{NaCl} 100 \mathrm{mmol}^{-1} \mathrm{I}^{-1}$ SDS $0.1 \%$ and DTT $50 \mathrm{mmol}^{-1}$ ) containing $0.1 \mathrm{mg}$ of proteinase $\mathrm{K}$. The homogenate was incubated for $2-4 \mathrm{~h}$ at $37^{\circ} \mathrm{C}$. After centrifugation (5 min at $1500 \mathrm{rpm}$ ), the supernatant was deproteinated by 2 successive phenol-chloroform extractions. Nucleic acids were subsequently ethanol precipitated and dissolved in $1 \mathrm{ml}$ of TE (10 mmol. -1 $^{-1}$ Tris, 1 mmol. ${ }^{-1}$ EDTA, pH 8.0).

\section{Sequencing}

The DNA template was produced through polymerase chain reaction (PCR) with the primers: E2: 5'-GGCAGAATAAGTGCATTG-3' located in the tRNAleu gene and $H 2$ : 5'-CAATATCATTGATGACC-3', 300 bp downstream from the 5 ' end of the CO-II gene (Cornuet et al, in press). Single-stranded DNA was obtained according to Higuchi and Ochman (1989): amplification was achieved with one kinased primer, the other being unchanged. After amplification, the strand with the 5'-terminal phosphate was specifically digested with lamda exonuclease. Sequencing was performed through the dideoxy chain-termination method (Sanger et al, 1977) with the Pharmacia sequencing kit. Both strands were sequenced for all species.

\section{Phylogeny reconstruction}

The Neighbor-Joining ( $\mathrm{N}-\mathrm{J}$ ) algorithm (Saitou and Nei, 1987) applied to corrected nucleotide distances (Kimura, 1980) and the parsimony method (program DNAPARS from the package PHYLIP v3.01) were used to infer phylogenetic trees.

\section{RESULTS AND DISCUSSION}

In the CO-II gene of each species, a region of 269 nucleotides was sequenced of which 93 were polymorphic and 41 informative (fig 1). The number of substitutions observed in pairwise comparisons and the corresponding distance are given in table $\mathrm{I}$. The tree obtained through the $\mathrm{N}-\mathrm{J}$ method indicates that the ancestor species diverged in 2 lineages giving rise to single comb open air species (dorsata and florea) and multiple comb cavity nesting species (mellifera and cerana) respectively (fig 2A). $A$ dorsata and $A$ florea then diverged rapidly, the separation of $A$ mellifera and $A$ cerana occurring later. The DNAPARS program provides 2 equiparsimonious trees. The first one has the same topology as above (fig $2 \mathrm{~A}$ ) and the second one infers a phylogeny in which florea diverged first, followed by dorsata and finally cerana and mellifera (fig 2B). Because of this discrepancy, a consensus tree is presented (fig 2C) in which dorsata and florea branch at the same level as the mellifera-cerana lineage. Solving this trifurcation would require far larger sequences because the level of homoplasy is high in mtDNA owing to the low number of sites able to substitute, the number of sites able to make multiple substitutions at these sites and to the simplified pattern of substitutions dominated by transitions and $A<->T$ transversions.

The early separation of $A$ florea, hypothetized by Michener (1974), is supported by a cladistic analysis of 19 morphological characters (Alexander, personal communication) and by the allozyme study of Sheppard and Berlocher (1989). Our sequence data, which are not opposed to this possi- 


\section{A. mel. lig. \\ A. mel. mel. \\ A. cerana \\ A. dorsata \\ A. florea \\ B. luconum \\ $X$. violacea}

A. mel. lig.

A. mel. mel.

A. cerano

A. dorsata

A. florea

B. huconum

$X$. violacea

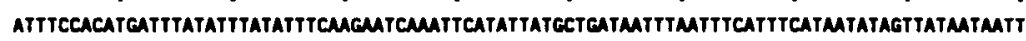

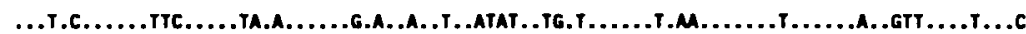
...T.T......TTC.....TA.A......G.A..A..T..ATAT..CG.T.....T.M............A..GTA.......T ...T.A.....ATA.....M.A......G.A..A..T..ATTT..TG.A.....T.M......T.....A..GTA.......A ...T.T......ATA.....TA.A.....G.A..A..С..ATTT..TG.T.....T.AG..............GTA.......T

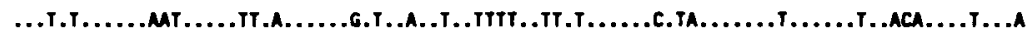

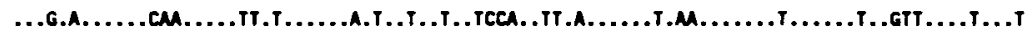

ATTATTATMATTCMCATTMCTGTATATATTATTTAGATTYATTTATMMCMATTCTCMUTTTATTTTATTMMMUTCATMI

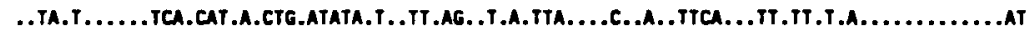

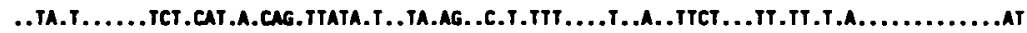

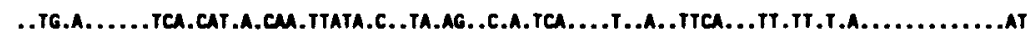

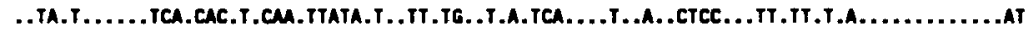
..M.A......ATT.CTT.A.CTA.ATTTT.C..TA.AG..T.T.CA....T..T..TTTA...TT.M.C.T............T

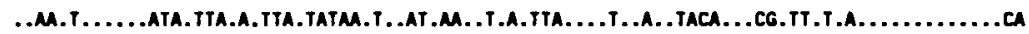

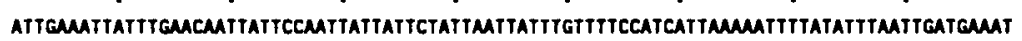

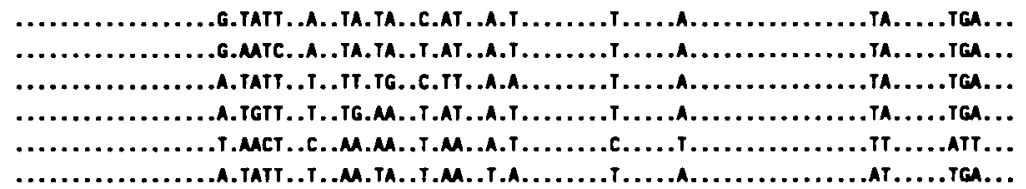

Fig 1. Nucleotide sequence of the 5'end of the mitochondrial DNA cytochrome-oxydase subunit II (COll) gene for four Apis species (Apidae), Bombus lucorum (Apidae) and Xylocopa violacea (Anthophoridae). The first line is the reference sequence of Apis mellifera lingustica (Crozier et al, 1989). Dots represent nucleotides common to all species.

Table I. Distances between taxa: number of observed substitutions between sequence and nucleotide distances with Kimura's correction (between parentheses).

\begin{tabular}{|c|c|c|c|c|c|}
\hline A m ligustica & A m mellifer & A cerana & A dorsata & A florea & B lucorum \\
\hline \multicolumn{6}{|l|}{$\begin{array}{c}\text { A mellifera mellifera } \\
4 \\
(0.0151 \pm 0.0076)\end{array}$} \\
\hline $\begin{array}{l}\text { A cerana } \\
\quad 19 \\
\quad(0.0744 \pm 0.0173)\end{array}$ & $\begin{array}{c}17 \\
(0.00661 \pm 0.0162)\end{array}$ & & & & \\
\hline $\begin{array}{l}\text { A dorsata } \\
25 \\
(0.0992 \pm 0.0202)\end{array}$ & $\begin{array}{c}25 \\
(0.0992 \pm 0.0202)\end{array}$ & $\begin{array}{c}27 \\
(0.1121 \pm 0.0216)\end{array}$ & & & \\
\hline $\begin{array}{l}\text { A florea } \\
\qquad \begin{array}{l}23 \\
(0.0909 \pm 0.0193)\end{array}\end{array}$ & $\begin{array}{c}26 \\
(0.1039 \pm 0.0208)\end{array}$ & $\begin{array}{c}26 \\
(0.1037 \pm 0.0208)\end{array}$ & $\begin{array}{c}26 \\
0.1036 \pm 0.0207)\end{array}$ & & \\
\hline $\begin{array}{l}\text { B lucorum } \\
52 \\
(0.2236 \pm 0.0325)\end{array}$ & $\begin{array}{c}52 \\
(0.2236 \pm 0.325)\end{array}$ & $\begin{array}{c}52 \\
(0.2236 \pm 0.0324)\end{array}$ & $\begin{array}{c}54 \\
(0.2338 \pm 0.0334)\end{array}$ & $\begin{array}{c}55 \\
(0.2387 \pm 0.0338)\end{array}$ & \\
\hline $\begin{array}{c}X \text { violacea } \\
46 \\
(0.1943 \pm 0.0298)\end{array}$ & $\begin{array}{c}47 \\
(0.1990 \pm 0.0302)\end{array}$ & $\begin{array}{c}55 \\
(0.2391 \pm 0.0339)\end{array}$ & $\begin{array}{c}52 \\
(0.2186 \pm 0.0320)\end{array}$ & $\begin{array}{c}51 \\
(0.2186 \pm 0.0320)\end{array}$ & $\begin{array}{c}56 \\
(0.2439 \pm 0.0343)\end{array}$ \\
\hline
\end{tabular}


A : Neighbor-Joining (Parsimony 1)

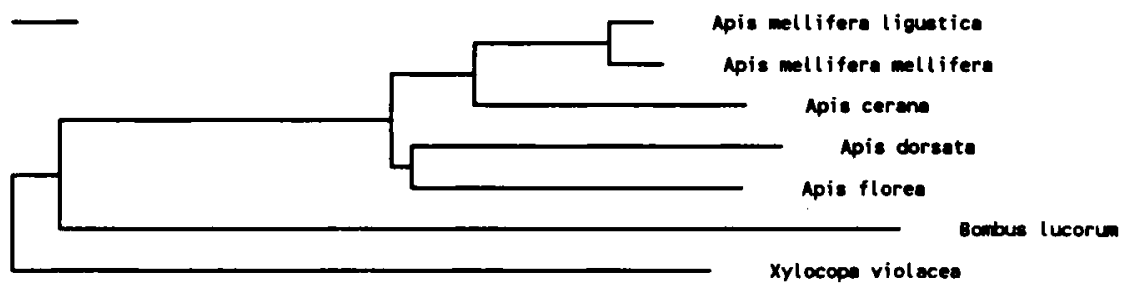

\title{
B : Parsimony 2
}

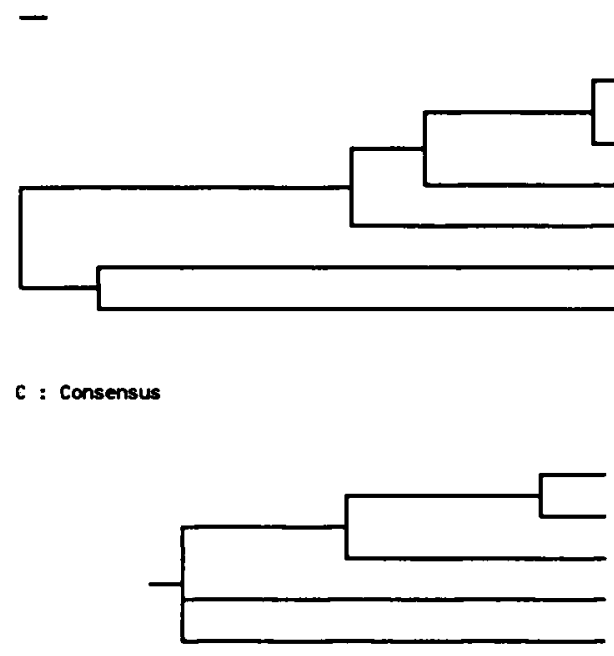

\author{
Apis mellifere ligustica \\ Apis mellifera mellifera \\ Apis cerane \\ Apis dorsata \\ Apis florea
}

Fig 2. Phylogenetic trees obtained through the Neighbor-Joining algorithm $(A)$ and parsimony method (B) and a consensus tree (C). In $A$ and $B$, the scale is indicated under the title: it corresponds to $1 \%$ divergence (A) and 1 substitution (B) respectively. The parsimony method gave two equiparsimonious trees, one of which had the same topology as the tree shown in $A$.

bility, indicate that $A$ florea and $A$ dorsata diverged almost simultaneously of the cluster $A$ mellifera - $A$ cerana, as considered by Ruttner (1988, fig 3.11).

Considering now the separation between $A$ cerana and $A$ mellifera, the allozyme study of Sheppard and Berlocher, by dating this event at the time of divergence of dorsata or slightly later casts doubt on the old and still widely accepted hypothe- sis that both species separated quite recently (Culliney, 1983; Ruttner, 1988). An intermediate situation is obtained with our present data: the divergence of $A$ cerana and $A$ mellifera is clearly posterior to the dorsata-(mellifera/cerana) node but the nucleotide distance between them is hardly compatible with a quaternary speciation.

Nucleotide distances between the different molecules can be used to calculate dis- 
tance between species and then the absolute time of divergence, provided the rate of evolution is known (Wilson et al, 1985). This rate is not known in Apis, but it has been found close to $2 \%$ per million year (mya) for the whole mtDNA genome in Diptera as well as in vertebrates (De Salle et al, 1987). The rate of evolution of the sequenced CO-II region is about half that of the whole genome (a similar ratio is found in Drosophila sequenced mtDNA).

The nucleotide distance between the CO-II region of mellifera and cerana is $7 \%$; the corresponding value for the whole genome would be $14 \%$; the nucleotide diversity of the ancestral species is assumed to be the same as in $A$ mellifera, ie $2 \%$ (unpublished results) and the rate of divergence $2 \%$ per mya. Their absolute time of speciation is then: $(14-2) / 2=6$ mya. A similar computation would date the trifurcation florea-dorsata-cerana/mellifera around -9 mya. These time values should be considered as underestimates, owing to a rapid saturation effect for substitutions in mtDNA (De Salle et al, 1987).

The trees have been rooted by way of 2 external species (Bombus lucorum and $x y$ locopus violacea), the relative position of which is irrelevant.

Résumé - Relations phylogénétiques dans le genre Apis déduites de données de séquences d'ADN mitochondrial. La séquence nucléotidique de l'extrémité 5 ' du gène de la sous-unité II de la cytochrome-oxydase mitochondriale a été obtenue par séquençage direct du produit de PCR (Polymerase chain reaction) de 4 espèces d'Apis (mellifera, cerana, dorsata et florea) et de Bombus lucorum (Apidae) et Xylocopa violacea (Anthophoridae) comme références externes. Des arbres phylogénétiques ont été construits à l'aide de la méthode du Neighbor-Joining et d'une méthode de parcimonie. L'arbre consensus indique que les 3 rameaux florea, dorsata et mellifera-cerana ont divergé à peu près à la même époque et que mellifera et cerana ont divergé plus tard, mais pas aussi récemment qu'on le croyait généralement.

Apis / phylogenèse / taxonomie moléculaire / ADN mitochondrial / séquence de nucléotides / cytochrome oxydase

Zusammenfassung - Versuch der Konstruktion eines phylogenetischen Baums aus den Sequenz-Daten der mitochondrialen DNA von vier Apis-Arten. Die Nukleotid-Sequenz des 5' Endes des mitochondrialen Gens der Untereinheit II der Cytochromoxydase wurde durch direkte Sequenzierung des PCR-Produkts (Polymerase Chain Reaktion) von 4 ApisArten (mellifera, cerana, dorsata und florea) und von Bombus lucorum und Xylocopa violacea als Außengruppen gewonnen. Mit Hilfe der Neighbor-Joining und einer Parsimony-Methode wurden phylogenetische Bäume konstruiert. Die Verzweigung dorsata, florea und ceranamellifera erfolgte offenbar beinahe gleichzeitig und mellifera trennte sich von cerana erst später, aber nicht erst in jüngster Vergangenheit wie allgemein angenommen wird.

Apis / Phylogenesis / molekulare Systematik / mitochondriale DNA / Nuckleotid-Sequenz / Cytochromoxydase

\section{REFERENCES}

Cornuet JM, Garnery L, Solignac M (1991) Putative origin and function of the intergenic region between $\mathrm{CO}-\mathrm{I}$ and $\mathrm{CO}-11$ of Apis mellifera $\mathrm{L}$ mitochondrial DNA. Genetics (in press)

Crozier RH, Crozier YC, McKinlay AG (1989) The CO-I and CO-Il region of honeybee mitochondrial DNA: evidence for variation in in- 
sect mitochondrial rates. Mol Biol Evol 6, 399-411

Culliney TW (1983) Origin and evolutionary history of the honey bees Apis. Bee World 64, 29-38

Desalle R, Freedman T, Prager EM, Wilson AC (1987) Tempo and mode of sequence evolution in mitochondrial DNA of Hawaiian Drosophila. J Mol Evol 26,157-164

Higuchi RG, Ochman H (1989) Production of single-stranded DNA templates by exonuclease digestion following the polymerase chain reaction. Nucleic Acids Res 17, 5865

Kimura M (1980) A simple method for estimating evolutionary rates of base substitutions. $J$ Mol Evol 16, 111-120

Kocher TD, Thomas WK, Meyer A, Edwards $S V$, Paabo S, Villablanca FX, Wilson AC (1989) Dynamics of mitochondrial DNA evolution in animals: Amplification and sequencing with conserved primers. Proc Natl Acad Sci USA 86, 6196-6200

McPheron BA (1989) Insect molecular systematics based on sequence data from several genes. ESA Annual meeting Dec 10-14,. San Antonio, Texas, USA
Michener CD (1974) The social behavior of the Bees. Harvard University Press, Cambridge, Massachusetts, $404 p$

Ruttner $F$ (1988) Biogeography and Taxonomy of Honeybees. Springer-Verlag, Berlin Heidelberg, $284 p$

Sanger F, Nicklen S, Coulson AR (1977) DNA sequencing with chain terminator inhibitors. Proc Natl Acad Sci USA 74, 5436-5437

Saitou N, Nei M (1987) The neighbor-joining method: a new method for reconstructing phylogenetic trees. Mol Biol Evol 4, 406-425

Sheppard WS (1989) Ribosomal RNA diversity in Apis. ESA Annual meeting Dec 10-14. San Antonio, Texas, USA

Sheppard WS, Berlocher SH (1989) Allozyme variation and differentiation among four Apis species. Apidologie 20, 419-431

Wilson AC, Cann RL, Carr SM, George M, Gyllenstein UB, Helm-bychowski, Higuchi RG, Palumbi SR, Prager EM, Sage RD, Stoneking $M$ (1985) Mitochondrial DNA and two perspectives on evolutionary genetics. Biol $J$ Linn Soc 26, 375-400 